\begin{tabular}{|c|c|c|}
\hline & Int.J.Curr.Microbiol.App.Sci (2017) 6(7): 102-108 & \\
\hline & $\begin{array}{l}\text { International Journal of Current Microbiology and Applied Sciences } \\
\text { ISSN: 2319-7706 Volume } 6 \text { Number } 7 \text { (2017) pp. 102-108 } \\
\text { Journal homepage: http://www.ijcmas.com }\end{array}$ & 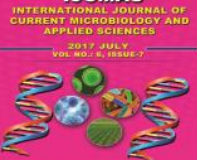 \\
\hline $\begin{array}{l}\text { EXCELLENT } \\
\text { PUBLISHERS }\end{array}$ & & \\
\hline
\end{tabular}

Original Research Article https://doi.org/10.20546/ijcmas.2017.607.012

\title{
Available Micronutrients in Relation to Soil Properties of Ghatol Tehsil, Banswara District of Rajasthan, India
}

\author{
R.S. Meena ${ }^{1 *}$ and A.K. Mathur ${ }^{2}$ \\ ${ }^{1}$ National Bureau of Soil Survey and Land Use Planning (ICAR), \\ Regional Centre, Udaipur, India \\ ${ }^{2}$ Department of Agricultural Chemistry and Soil Science, Rajasthan College of Agriculture, \\ MPUAT, Udaipur-313001, India \\ *Corresponding author
}

\begin{tabular}{|c|c|}
\hline \multicolumn{2}{|r|}{ A B S T R A C T } \\
\hline & \multirow{6}{*}{$\begin{array}{l}\text { The present study was undertaken to assess the status of micronutrients in relation to soil } \\
\text { properties in one hundred soil samples collected from different locations of } 25 \text { villages } \\
\text { representing the soils of Ghatol tehsil, Banswara district of Rajasthan. In general, textural } \\
\text { class of soils was found to be the category of sandy clay loam, clay loam and clay. The } \\
\text { content of sand fraction varied from } 17.61 \text { to } 65.44 \text { per cent with a mean value of } 42.58 \\
\text { per cent, silt fraction varied from } 10.00 \text { to } 47.90 \text { per cent with a mean value of } 26.75 \text { per } \\
\text { cent and clay fraction varied from } 17.65 \text { to } 53.07 \text { per cent with a mean value of } 30.54 \text { per } \\
\text { cent. The pH of soils varied from } 7.07 \text { to } 8.02 \mathrm{with}^{-1} \text { mean value of } 7.52 \text {, EC varied from } \\
0.34 \text { to } 0.79 \mathrm{dSm}^{-1} \text { with a mean value of } 0.54 \mathrm{dSm}^{-1}, \mathrm{OC} \text { varied from } 3.74 \text { to } 9.91 \mathrm{~g} \mathrm{~kg}^{-1} \\
\text { with a mean value of } 6.58 \mathrm{~g} \mathrm{~kg}^{-1}, \mathrm{CaCO}_{3} \text { ranged from } 8.00 \text { to } 68.00 \mathrm{~g} \mathrm{~kg}^{-1} \text { with a mean } \\
\text { value of } 31.67 \mathrm{~g} \mathrm{~kg}^{-1} \text { and CEC ranged from } 7.00 \text { to } 40.00 \mathrm{cmol}(\mathrm{p}+) \mathrm{kg}^{-1} \text {. Available Zn } \\
\text { ranged between } 0.42 \text { to } 1.95 \mathrm{mg} \mathrm{kg}^{-1} \text { with a mean value of } 0.84 \mathrm{mg} \mathrm{kg}^{-1} \text {, available Fe } \\
\text { ranged from } 2.26 \text { to } 28.4 \mathrm{mg} \mathrm{kg}^{-1} \text { with a mean value of } 10.12 \mathrm{mg} \mathrm{kg}^{-1} \text {. Available Cu ranged } \\
\text { between } 0.37 \text { to } 4.15 \mathrm{mg} \mathrm{kg}^{-1} \text { with a mean value of } 1.07 \mathrm{mg} \mathrm{kg}^{-1} \text {. Available Mn ranged } \\
\text { between } 2.10 \text { to } 21.85 \mathrm{mg} \mathrm{kg}^{-1} \text { with a mean value of } 9.36 \mathrm{mg} \mathrm{kg}^{-1} \text {. Organic carbon, clay, } \\
\text { and CEC were positively correlated with available } \mathrm{Zn}, \mathrm{Fe}, \mathrm{Cu}^{2} \text { and Mn while pH, CaCO } \\
\text { and sand were negatively correlated. }\end{array}$} \\
\hline Keywords & \\
\hline $\begin{array}{l}\text { Available } \\
\text { micronutrients } \\
\text { status, Fertility } \\
\text { status, Correlation, } \\
\text { Critical limit. }\end{array}$ & \\
\hline Ar & \\
\hline & \\
\hline & \\
\hline
\end{tabular}

\section{Introduction}

The optimum plant growth and crop yield depends not only on the total amount of nutrients present in the soil at a particular time but also on their availability which in turn is controlled by physical and chemical properties of soil. Now-a-days, the agricultural productivity trends to decline due to increased removal of micronutrients resulting from adoption of high yielding varieties and intensive cropping to meet the ever increasing demand of food grains production along with the shift towards high analysis NPK fertilizers and limited use of organic manures during the last three decades (Mathur et al., 2006); Somasundaram et al., 2009; Sharma et al., 2009). Due to the pressure on soil for increasing productivity of the crops after the green revolution in India in 1960s, the native soils began depleting of their nutrient reserves and the crops started responding to micronutrient fertilizers in spite of balanced fertilization with major nutrients. 
Micronutrients namely, zinc $(\mathrm{Zn})$, iron $(\mathrm{Fe})$, copper $(\mathrm{Cu})$, manganese $(\mathrm{Mn})$ and boron $(\mathrm{B})$ are essential nutrients required in very small quantities for normal plant growth. Micronutrients are involved in various enzymes and other physiologically active molecules (Gao et al., 2008), although each micronutrient has specific functions in plants and in microbial growth processes. The deficiency and toxicity range in soil of these micronutrients is narrow; therefore the proper assessment of micronutrient status, before their supplementation through internal sources in soil is very important. Micronutrient availability is influenced by numerous soil parameters like, soil $\mathrm{pH}$, organic content, adsorptive surfaces and other physical, chemical and biological conditions in the rhizosphere zone (Pati and Mukhopadhyay, 2011). Soils having heavy texture, lower $\mathrm{pH}$ and higher organic matter can generally provide a greater reserve of these elements, whereas, corse textured soils such as sand have fewer reserve and tend to get depleted rather quickly (Yadav and Meena, 2009). Micronutrient availability under southern part of Rajasthan may be influenced by different physiographic regions having difference in soil properties which may finally affect the optimum crop yield. Hence, there is a need to generate database on the status of micronutrients and their deficiency in soils. Agro-ecological zone wise generation of such information is a better approach than done from a particular site. The productivity of soil mainly depends upon its ability to supply nutrients to the growing plants. The crop productivity can be increased by utilizing the available basic information related to soil analysis, use of agro-ecosystem and management practices of soil.

The improper nutrient management has led to emergence of multinutrient deficiencies in the Indian soils (Sharma, 2009). Keeping this in view, the present investigation was carried out to know the distribution of DTPA- $\mathrm{Zn}, \mathrm{Fe}, \mathrm{Cu}$ and $\mathrm{Mn}$ and their relationship with soil properties in Ghatol Tehsil.

\section{Materials and Methods}

\section{Description of study area}

Ghatol tehsil comprising a part of Agroclimatic Zone (IV-b) of Rajasthan. Geographical location of Ghatol tehsil is $23^{0}$ 45 ' 35.04' N latitudes and $74^{0} 24$ ' 47.06' E longitudes with an area of 130499 hectare.

\section{Climate}

The climate of Ghatol tehsil is semi-arid characterized by extremes of temperature and low wind velocity.

During the summers, the temperature of Ghatol tehsil remains quite high, like in any other parts of Banswara district. The temperature however, varies between $31^{\circ} \mathrm{C}$ to $44^{\circ} \mathrm{C}$ in summer months. The annual rainfall in Ghatol tehsil of Banswara district is about $852 \mathrm{~mm}$.

\section{Geology}

The geology of the study area is quite complex. It consists of (1) Archaean age, representing the granite gneissic complex, (2) Aravali system, consisting of quartzite-schists formation and (3) Deccan trap. The geological rock formation belonging to different era and periods are of marked significance.

\section{Present land use}

There are two main crop seasons, kharif and rabi. Kharif season begins in June and ends between September to October, while rabi season viz., starts from October and ends in April. The major crops of Banswara district in kharif season are sorghum, maize, soyabeen, castor and cotton. In rabi season wheat, 
mustard, barley, gram and poppy are major crops.

\section{Soil sampling}

One hundred representative composite soil samples from a depth of $0-15 \mathrm{~cm}$ were collected with the help of a wooden Khurpi. Samples were completely air-dried and passed through $2 \mathrm{~m}$ sieve and stored in properly labeled plastic bags for analysis.

\section{Soil analysis}

Soil $\mathrm{pH}$ was measured in 1:2.5 soil water suspension using glass electrode $\mathrm{pH}$ meter. Electrical conductivity was measured in 1:2.5 soil water supernatant solution with the help of conductivity bridge (Jackson, 1973). The organic carbon was determined by rapid titration method (Walkley and Black, 1934) and $\mathrm{CaCO}_{3}$ by rapid titration method (Puri, 1930). The available $\mathrm{Zn}$ and $\mathrm{Fe}$ in soil samples were extracted with DTPA $(0.005 \mathrm{M}$ DTPA + 0.01 $\mathrm{M} \mathrm{CaCl}_{2}+0.1 \mathrm{M}$ TEA, $\mathrm{pH}$ 7.3) as per the method described by Lindsay and Norvell (1978) and the concentration of Zn, $\mathrm{Fe}, \mathrm{Cu}$ and $\mathrm{Mn}$ in the DTPA-extract was determined using atomic absorption spectrophotometer.

\section{Results and Discussion}

\section{Physico-chemical properties}

The data presented in table 1 on soil properties showed that the sand content ranged between 17.61 to 65.44 per cent with a mean value of 42.58 per cent, silt content varied from 10.00 to 47.90 per cent with a mean value of 26.75 per cent and clay content varied from 17.65 to 53.07 per cent with a mean value of 30.54 per cent. The soils are neutral to moderately alkaline (7.07 to 8.02$)$. The alkaline nature of soil under study is attributed to the fairly optimum base saturation in the region (Sharma et al., 1992).
The electrical conductivity (EC) ranged from 0.34 to $0.79 \mathrm{dSm}^{-1}$ with a mean value of 0.54 $\mathrm{dSm}^{-1}$. All of the soil samples are under $<1$ $\mathrm{dSm}^{-1}$. It indicates that they are less saline in nature as suggested by Muhr et al., (1963) comparatively low content of soluble salts appear to be due to the type of climate (subhumid) of the area which is fairly sufficient to leach out major part of soluble salts from the soil. The organic carbon ranged from 3.74 to $9.91 \mathrm{~g} \mathrm{~kg}^{-1}$ soil with a mean value of $6.58 \mathrm{~g}$ $\mathrm{kg}^{-1}$ soil. It showed a considerable variation with types and topography of soil. Relatively higher values of organic carbon can be ascribed to annual addition of plant residues and also the application of FYM. The $\mathrm{CaCO}_{3}$ raged from 8.00 to $68.00 \mathrm{~g} \mathrm{~kg}^{-1}$ with a mean value of $31.67 \mathrm{~g} \mathrm{~kg}^{-1}$ is a useful parameter to assess the extent of nutrient availability and their release behavior. The CEC values ranged from 7.00 to $40.00 \mathrm{cmol}\left(\mathrm{p}^{+}\right) \mathrm{kg}^{-1}$ with a mean value of $20.77 \mathrm{cmol}\left(\mathrm{p}^{+}\right) \mathrm{kg}^{-1}$.

\section{Available zinc}

DTPA-zinc ranged between 0.42 to $1.95 \mathrm{mg}$ $\mathrm{kg}^{-1}$ with a mean value of $0.84 \mathrm{mg} \mathrm{kg}^{-1}$. Clay and silt are the most active fractions of soil. Most of the zinc bearing minerals such as biotite, hornblende, augite and others are easily weathered and thus released zinc is subjected to secondary soil forming processes such as adsorption of $\mathrm{Zn}^{2+}$ ions by clay.

Zinc $\left(\mathrm{Zn}^{2+}\right)$ ions adsorbed on soil complexes may easily be removed by leaching especially in sandy loam soils and adsorbed zinc is in equilibrium with the soil solution zinc. The amount of extracted zinc is likely to increase with the increase in fineness of the soil texture. It has also been reported that organic matter plays an important role in controlling availability of zinc particularly in alkaline soils (Das, 2000). A close examination of the data in table 2 indicates significant increase in zinc content with increase in organic carbon $(r$ $=0.684 * *)$. 
Table.1 Ranges and mean values of physico-chemical properties of soils of Ghatol tehsil

\begin{tabular}{|c|c|c|c|c|c|c|c|c|c|c|c|c|}
\hline \multirow[t]{4}{*}{ Ranges } & \multicolumn{12}{|c|}{ Soil properties } \\
\hline & \multirow{3}{*}{$\begin{array}{c}\text { Sand } \\
(\%)\end{array}$} & \multirow[t]{3}{*}{ Silt (\%) } & \multirow[t]{3}{*}{ Clay (\%) } & \multirow[t]{3}{*}{ pH } & \multirow{3}{*}{$\begin{array}{c}\mathrm{EC} \\
\left(\mathrm{dSm}^{-1}\right)\end{array}$} & \multirow{3}{*}{$\begin{array}{c}\text { OC } \\
\mathrm{g} \mathrm{k}^{-1}\end{array}$} & \multirow{3}{*}{$\begin{array}{c}\mathrm{CaCO}_{3} \\
\mathrm{~g} \mathrm{k}^{-1}\end{array}$} & \multirow{3}{*}{$\begin{array}{c}\text { CEC cmol } \\
(p+) k^{-1}\end{array}$} & \multicolumn{4}{|c|}{ Micronutrients } \\
\hline & & & & & & & & & $\mathbf{Z n}$ & $\mathbf{F e}$ & $\mathrm{Cu}$ & Mn \\
\hline & & & & & & & & & \multicolumn{4}{|c|}{$\mathrm{mg} \mathrm{k}^{-1}$} \\
\hline Maximum & 65.44 & 47.90 & 53.07 & 8.02 & 0.79 & 9.91 & 68.00 & 40.00 & 1.95 & 28.4 & 4.15 & 21.85 \\
\hline Minimum & 17.61 & 10.00 & 17.65 & 7.07 & 0.34 & 3.74 & 8.00 & 7.00 & 0.42 & 2.26 & 0.37 & 2.10 \\
\hline Mean & 42.58 & 26.75 & 30.54 & 7.52 & 0.54 & 6.58 & 31.67 & 20.77 & 0.84 & 10.12 & 1.07 & 9.36 \\
\hline
\end{tabular}

Table.2 Correlations between soil properties and available micronutrients of soils of Ghatol tehsil

\begin{tabular}{|c|c|c|c|c|c|c|c|c|}
\hline \multirow[t]{2}{*}{ Micronutrients } & \multicolumn{8}{|c|}{ Soil properties } \\
\hline & Sand $(\%)$ & Silt (\%) & Clay (\%) & pH & $\mathrm{EC}\left(\mathrm{dSm}^{-1}\right)$ & ${\mathrm{OC} \mathrm{g} \mathrm{k}^{-1}}^{-1}$ & $\mathrm{CaCO}_{3} \mathrm{~g} \mathrm{k}^{-1}$ & CEC cmol $(p+) \mathrm{kg}^{-1}$ \\
\hline $\mathbf{Z n}$ & -0.044 & 0.045 & 0.032 & -0.265 & -0.036 & 0.684 & -0.628 & 0.051 \\
\hline $\mathbf{F e}$ & -0.019 & -0.014 & 0.057 & 0.011 & 0.011 & 0.607 & -0.449 & 0.017 \\
\hline $\mathbf{C u}$ & -0.018 & 0.083 & -0.063 & -0.056 & 0.047 & 0.703 & -0.421 & 0.056 \\
\hline Mn & -0.004 & 0.009 & -0.015 & -0.266 & 0.008 & 0.928 & -0.536 & 0.006 \\
\hline
\end{tabular}

Level of significance at.05\% (**) and.01\% (*) 
The availability of zinc increased significantly with increase in organic carbon because zinc forms soluble complexes (Chelates) with soil organic matter component. On the other hand, the availability of zinc reduced significantly with an increase in $\mathrm{CaCO}_{3}(\mathrm{r}=-0.628 * *)$ and $\mathrm{pH}\left(\mathrm{r}=-0.265^{* *}\right)$ of soil. At high $\mathrm{pH}$ and $\mathrm{CaCO} 3$ content, zinc forms insoluble compounds such as $\mathrm{Zn}(\mathrm{OH})_{2}$ and $\mathrm{ZnCO}_{3}$ which can reduce the availability of zinc. There was inverse relationship between zinc and $\mathrm{pH}$ as the $\mathrm{pH}$ increases the availability of zinc decreased. The findings of the present investigation are confirmed by the results of Singh (2006) and Mehra (2007).

\section{Available iron}

The data resented in table 1 showed that DTPA-iron ranged from 2.26 to $28.4 \mathrm{mg} \mathrm{kg}^{-1}$ with a mean value of $10.12 \mathrm{mg} \mathrm{kg}^{-1}$. The available iron significantly increased with increase in organic carbon $(\mathrm{r}=0.607 * *)$. On the other hand the availability of iron was reduced significantly with an increase in $\mathrm{CaCO}_{3}$ ( $\left.\mathrm{r}=-0.449 * *\right)$. It was significantly increased with increase in finer fractions (silt and clay) because these fractions are helpful improving the soil structure and aeration of soils. The available iron was found to increase with increase in CEC of soils due to more availability of exchange sites on soil colloids. The availability of iron enhanced significantly with increase in organic matter because (i) organic matter is helpful in improving soil structure and aeration conditions, (ii) organic matter protect the oxidation and precipitation of iron into unavailable forms and (iii) supply of chelating agents, which increase the solubility of iron compounds. On the other hands, its availability was found to be reduced with increase in $\mathrm{pH}_{2}$ and $\mathrm{CaCO}_{3}$ contents of soils. Most readily available form of iron is $\mathrm{Fe}^{2+}$ ions, which convert into less soluble form $\left(\mathrm{Fe}^{3+}\right.$ ions) after oxidation. High $\mathrm{pH}$ is responsible for its oxidation. Hence, the availability of iron reduced at higher $\mathrm{pH}$ level. Beside this, at high $\mathrm{pH}$ iron is also precipitated as insoluble $\mathrm{Fe}(\mathrm{OH})_{3}$ which reduces its availability. The $\mathrm{CaCO}_{3}$ present in soils gets converted into bicarbonates ions which reduces the availability of iron and the chlorosis caused in these conditions is known as a "lime induced chlorosis". The availability of iron at high $\mathrm{pH}$ is reduced due to the reduction in its solubility. The solubility of iron decreased with increase in $\mathrm{pH}$ is due to the formation of insoluble iron hydroxide and carbonates. Similar results were reported by Gupta (2003) and Yadav and Meena (2009).

\section{Available copper}

The data presented in table 1 showed that DTPA-copper varied from 0.37 to $4.15 \mathrm{mg}$ $\mathrm{kg}^{-1}$ with a mean value of $1.07 \mathrm{mg} \mathrm{kg}^{-1}$. As given in table 2 the available copper significantly increased with increase in organic carbon $\left(\mathrm{r}=0.703^{* *}\right)$. On the other hand the availability of copper was reduced significantly with an increase in $\mathrm{CaCO}_{3}(\mathrm{r}=-$ $\left.0.421^{*}\right)$ and $\mathrm{pH}(\mathrm{r}=-0.056)$. The organic acid molecules present in organic matter solubilise $\mathrm{Cu}^{2+}$ ions by chelation and complexion and as a result of this organic binding, there is more dissolved copper in the soil solution than normally occurs in the absence of organic matter. Furthermore the availability of copper enhanced with increase in silt and clay contents and this might be due to the improvement of soil structure and aeration conditions of soils with increase in finer fractions in soil mass. The availability of copper suppresses significantly with sand contents because the coarseness of soil texture reduces the adsorption of $\mathrm{Cu}^{2+}$ ions on exchange sites. The availability of copper reduces at high $\mathrm{pH}$ and high $\mathrm{CaCO}_{3}$ content due to the formation of less soluble compounds like $\mathrm{Cu}(\mathrm{OH})_{2}$ and $\mathrm{CuCO}_{3}$. Similar results were reported by Singh et al., (2013). 


\section{Available manganese}

The data presented in table 1 showed that DTPA-manganese varied from 2.10 to 21.85 $\mathrm{mg} \mathrm{kg}^{-1}$ with a mean value of $9.36 \mathrm{mg} \mathrm{kg}^{-1}$. A close examination of data in table 2 indicates that the availability of manganese in these soils enhanced with increase in clay $(\mathrm{r}=$ $0.015)$, organic carbon $(\mathrm{r}=0.928 * *)$, and CEC $(\mathrm{r}=0.006)$. There was a positive correlation between manganese and organic carbon as the organic carbon content increases the availability of manganese increases. The increase in availability of manganese with increase in clay and silt might be due to the improvement in soil structure and aeration conditions. On the other hand the availability of manganese was reduced significantly with an increase in $\mathrm{CaCO}_{3}\left(\mathrm{r}=-0.536^{* *}\right)$ and $\mathrm{pH}\left(\mathrm{r}=-0.266^{* *}\right)$. It might be due to the formation of less soluble compounds like $\mathrm{MnCO}_{3}$ or $\mathrm{Mn}(\mathrm{OH})_{2}$. The higher $\mathrm{pH}$ favors the formation of less soluble organic complexes of $\mathrm{Mn}$, which reduces the availability of $\mathrm{Mn}$ and the activity of soil micro-organism which oxidizes soluble $\mathrm{Mn}^{2+}$ (Singh et al., 2013).

\section{References}

Das, D.K. (2000). Micronutrients: Their behavior in soils and plants. Kalayani Publishers, New Delhi.

Gao, S., Yan, R., Cao, M., Yang, W., Wang, S. and Chen, F. (2008). Effects of copper on growth, antioxidant enzymes and phenylalanine ammonia-lyase activities in Jatropha curcas L. Plant, Soil and Environment 54, 117-122.

Gupta, K. (2003). Available micronutrient status and their effect on soil properties of Nagaur Tehsil (Rajasthan). M.Sc. (Ag.) Thesis, RAU, Bikaner.

Jackson, M.L. (1973). Soil Chemical Analysis. Prentice Hall of India Private Limited, New Delhi.
Lindsay, W.L. and Norvell, W.A. (1978). Development of DTPA soil test for zinc, iron, manganese and copper. Soil Science Society of America Journal 42, 421-428.

Mathur, G.M., Ram Deo and Yadav, B.S. (2006). Status of zinc in irrigated northwest plain soils of Rajasthan. Journal of Indian Society Soil Science 53, 359-361.

Mehra, R.K. and Jat, J.R. (2007). To delineate the area of sufficiency and deficiency of micronutrients and their relationship with soil properties of Mokala soil series. M.Sc. (Ag.) Thesis, RAU, Bikaner.

Muhr, G.R., Datta, N.P., Shankar Subraney, N., Dever, F., Lecy, V.K. and Donanhue, R.S. (1963). Soil testing in India Published by USAID Mission to India.

Pati, R. and Mukhopadhyay, D. (2011). Distribution of cationic micronutrients in some acid soils of West Bengal. Journal of Indian Society Soil Science 59, 125-133.

Puri, A.N. (1930). A new method of estimating total carbonates in soils. Journal of Imperial Agriculural Research, Pusa bulletin 206, 7.

Sharma, B.D., Raj K., Singh, B. and Sethia, M. (2009). Micronutrients distribution in salt affected-soils of the Punjab in relation to soil properties. Archives of Agronomy and Soil Science 55, 367377.

Sharma, S.K. and Lal, F. 1992. Status of DTPA-extractable zinc in soils of humid southern zone of Rajasthan. Journal of the Indian Society of Soil Science 40, 393-394.

Singh, B.K. (2006). Available micronutrient status and their relationship with soil properties of Sangaria Tehsil of Hanumangarh District (Rajasthan). M.Sc. (Ag.) Thesis, RAU, Bikaner.

Singh, D.P., Yadav, K.K. and Qureshi, F.M. 
(2013). Available micronutrient status, their relationship with soil physicochemical properties and content in wheat crop of semi-arid eastern plain zone of Rajasthan. Green Farming. 4(2), 137-142.

Somasundaram, J., Singh, R.K., Parandiyal, A.K. and Prasad, S.N. (2009). Micronutrient status of soils under different land use system in Chambal ravines. Journal of Indian Society Soil Sci12.
Walkley, A. and Black, I.A. (1934). An examination of the Degtjareff method for determinating soil organic matter and a proposed modification of the chromic acid titration method. Soil Science 34, 29-38.

Yadav, R.L. and Meena, M.C. (2009). Available micronutrient status and their relationship with soil properties of Degana soil series of Rajasthan. Journal of Indian Society Soil Science 57, 90-92.

\section{How to cite this article:}

Meena, R.S. and Mathur, A.K. 2017. Available Micronutrients in Relation to Soil Properties of Ghatol Tehsil, Banswara District of Rajasthan. Int.J.Curr.Microbiol.App.Sci. 6(7): 102-108. doi: https://doi.org/10.20546/ijcmas.2017.607.012 